\section{End of the beginning}

\section{Washington}

ACTION to reform the state of US science education is finally getting under way after two years of complaints of falling standards. Last week saw two separate congressional hearings on bills designed to promote mathematics and science education and a national summit on the reform of science education organized by the Triangle Coalition - a group uniting 19 science and engineering societies, industry and 32 education associations. These developments came on top of the restructuring, announced earlier in the month, of the National Science Foundation (NSF)'s Science and Engineering Education Directorate and the surprise firing of its director by NSF chief Erich Bloch.

Reports showing that US schoolchildren come close to the bottom in international comparisons of mathematics and scientific achievement have appeared with almost monotonous regularity over the past few years. New impetus for change came when President George Bush set ambitious educational goals in his State of the Union address in January. By the year 2000, Bush demanded that US students reach a set of goals including being "first in the world in mathematics and science achievement". Although Bush did not spell out how to reach these goals, support for them came at a meeting in February of the state governors who carry much of the responsibility for US education.

Attempts to reform science education are thus "at the end of the beginning", according to the Triangle Coalition's executive director John Fowler. The coalition, which includes the American Association for the Advancement of Science (AAAS), the Federation of American Societies for Experimental Biology (FASEB) and the American Physical Society among its members, has attempted to define the opportunities for change in a series of reports over the past two years. Last week, it moved to the next stage with a triple offensive intended to build support for the rewriting of the school science curriculum, increase public awareness of the need for improved science education and expand local initiatives to help individual schools improve their standards.

Bringing in change is difficult because the 50 states of the United States (divided into 16,000 school districts) all have differing economic and social problems, standards of education and curriculum requirements. Reform movements are aimed both at the top-down approach of improving state science curricula (for which the Triangle Coalition appeals for support from scientific societies) and improving teacher training to the bottomup approach intended to find local support scientists in industry. hashiri. GENOME RESEARCH

from industry to provide computers for schools, improve science museums and expand contracts between teachers and

The National Science Foundation had been involved in the support of science education for years. But it was dissatisfaction over NSF's performance and the continuing debate over whether NSF puts its research budget before its education budget that led to a series of contradictory moves there over the past few weeks. Out went Bassam Shakhashiri, fired after six years as head of the Directorate for Science and Engineering Education. apparently because his demands for a bigger budget were too vociferous and sometimes appeared to by-pass Bloch. But in came a new, strengthened Directorate for Education and Human Resources, which will add programmes to encourage women, minorities and people with disabilities to study science to the programmes that had been run by Shak-

The increased stress on women and minorities comes because of a projected shortfall of scientists and engineers. Most US scientists and engineers are white males. Hispanics comprise 9 per cent of the population, but only 2 per cent of all

\title{
Green scheme avoids quarrels
}

\section{Washington}

THE four major US government agencies involved in mapping and sequencing of plant genomes agreed last week to join forces and create a single project, focusing on Arabidopsis thaliana, in order to avoid the kind of inter-agency rivalries that marred the beginnings of the Human Genome Project. The decision follows a meeting in Vienna earlier this month at which researchers from Europe, the United States, Japan and Australia agreed to coordinate national research efforts on the genome which are expected to cost $\$ 100$ million over the next ten years.

The National Science Foundation will lead US research efforts, coordinating the work of the National Institutes of Health, the Department of Energy and the Department of Agriculture. Combined, the four US agencies currently spend about $\$ 6$ million a year on Arabidopsis. But driven by support in the community for a largescale project, they have asked for an additional $\$ 20$ million next year. In the United Kingdom, a new initiative by the Agricultural and Food Research Council will spend $\$ 2$ million on Arabidopsis this year. The European Communities, as part of their BRIDGE programme, plan to spend $\$ 3$ million ECU in 1991 . employed scientists and engineers. NSF predicts a shortfall of scientists and engineers of over 600,000 by the year 2020 , owing to a declining interest in scientific careers and falling birth rates.

In Congress last week, the Senate Committee on Governmental Affairs held a hearing on a bill to establish a federal council to promote and coordinate mathematics and science education. Senator John Glenn (Democrat, Ohio) claimed that "lack of coordination" and inefficiency is evident in the thousand million dollars spent each year by more than a dozen agencies on science and mathematics education. In asking for increased federal control, the hearing represented one side of efforts to improve science education. The other, stressed at a second hearing at the House of Representatives subcommittee on science research and technology, included local efforts to interest people in science through better science teaching, including the use of interactive computer methods, and more attractive displays at science museums.

The Museum of Science in Boston already claims "more paid admissions" than to the city's baseball, football, hockey and basketball games combined. A newer success comes from the "BodyTech" exhibition on which NSF has spent $\$ 288,000$, at the North Carolina Museum of Life and Science. Shigeko Segawa
US plant genome researchers have taken pains to see that the effort concentrates on existing laboratories rather than new centres, a distinction that proved a problem for the Human Genome Project. Work is likely to be divided among existing laboratories. Two new biological libraries will store and distribute seeds and DNA fragments, and help distribute information and coordinate the project. Because the plant genome community is relatively small and closely knit, redundant research is unlikely to be a problem, says Chris Somerville, a Michigan state researcher who is a member of the project's steering committee.

The small size of the genome (at 100,000 kilobase pairs, it is about one thirtieth the size of the human genome), and the speed at which the plant reproduces, make it an ideal subject for study. Within two years, the project is expected to have a set of overlapping yeast artificial chromosome (YAC) clones which cover the entire genome. The work has been mostly done for about half of the project, says Somerville. Five years from the start of the project, all of the more interesting Arabidopsis genes should have been mapped and their functions explored. Five years beyond that, the entire genome should have been sequenced. G. Christopher Anderson 